absent in six out of 24 patients who presented with recurrent chest infections but who had normal serum IgG immunoglobulin levels. Three had normal levels of IgG or IgM or both, but three had depression of serum IgM. One patient was suffering from chronic lymphatic leukaemia. Five of these patients were subsequently treated with gammaglobulin injections which resulted in a reduction in the frequency of their infections. IgG levels in three patients subsequently fell to subnormal levels, suggesting that the absence of $E$. coli antibody occurred before a quantitative immunoglobulin deficiency.

About $70 \%$ of normal subjects have haemagglutinating $E$. coli antibody which is destroyed by mercaptoethanol. This finding supports previous contentions (Michael and Rosen, 1963) that much of the serum antibody against Gram-negative organisms is of the IgM type. It is not possible, however, to make any statements about the quantity of IgG antibody present since haemagglutinating techniques favour the recognition of IgM. Nevertheless, about $30 \%$ of normal adults have haemagglutinating antibody of the $7 \mathrm{~S}$ variety (mercaptoethanol resistant). This is likely to be IgG antibody, which is in keeping with the observations of Cohen and Norins (1968). The common occurrence of IgG antibodies to $E$. coli probably explains why we found no correlation between the level of serum IgM and the titre of $E$. coli antibody or between the titre of isohaemagglutinins and $E$. coli antibody in patients studied. Despite the absence of $\boldsymbol{E}$. coli antibodies in most of the patients with hypogammaglobulinaemia there were no cases of lower or upper urinary tract infection. It is exceptional for such patients to suffer from any infective complica- tion of the urinary tract, and in our wider series of about $\mathbf{7 0}$ patients (18 females) there was only one case of recurrent cystitis and this was associated with a sterile pyuria.

It is possible that a defect in the production of $E$. coli antibody may be due to a specific defect in the response to polysaccharide antigens. Work with mice has shown that some of these responses are independent of thymic processed $\mathbf{T}$ cells (Baker et al., 1970). For this reason, the presence of $E$. coli antibodies does not rule out the possibility of a clinically significant and treatable defect in the antibody response to protein antigens. Assessment of responses after immunization with antigens such as pneumococcal polysaccharide and haemocyanin may show such a dichotomy.

We thank Jill Boler, Margaret Kinsley, Margaret North, Lillian Racine, Stuart Line, and the technicians of our blood transfusion laboratory for their excellent help. We are also most grateful to Dr. B. Rowe, Salmonella and Shigella Reference Laboratory, Colindale, for supplying the $E$. coli serotypes and to the physicians who allowed us to study their patients.

\section{References}

Kunin, C. M. (1962). Archives of Internal Medicine, 110, 182

Rowe, D. S., Grab, B., and Anderson, S. G. (1972). Bulletin of the World Health Organization, 46, 67.

Andersen, H. J. (1967). Acta Paediatrica Scandinavica, 56, 637

Michael, J. G., and Rosen, F. S. (1963). fournal of Experimental Medicine,

118, 619.
Cohen, I. R., and Norins, L. C. (1968). Fournal of Clinical Investigation, 47, 1053.

Baker, P. J., et al. (1970). fournal of Immunology, 105, 1581.

\title{
Linoleate and Fatty-acid Patterns of Serum Lipids in Multiple Sclerosis and Other Diseases
}

\author{
W. CLAYTON LOVE, A. CASHELL, M. REYNOLDS, NOEL CALLAGHAN
}

British Medical fournal, 1974, 3, 18-21

\section{Summary}

The linoleic acid content of serum lipids was measured in 47 patients with multiple sclerosis, 29 patients with other neurological diseases, 35 patients with acute non-neurological illnesses, and 49 healthy control subjects. Reduced linoleic acid content of serum lipids was not specific to multiple sclerosis and occurred in all ill patients with acute non-neurological illness. The fatty-acid pattern of serum lipids in illness resembles that of essential fattyacid deficiency. It seems that this pattern of reduced linoleic acid content with increased oleic, palmitic, and palmitoleic acid content may be a general phenomenon in ill patients.

Clinical Biochemistry Laboratory, Trinity College, Dublin, Ireland W. CLAYTON LOVE, M.SC., PH.D., Senior Lecturer in Clinical Biochemistry

Department of Neurology, St. Finbarr's Hospital, Cork, Ireland A. CASHELL, B.SC., Research Assistant

M. REYNOLDS, B.sC., Research Assistant

NOEL CALLAGHAN, M.D., F.R.C.P., Consultant Neurologist

\section{Introduction}

The linoleic acid content of serum lipids is decreased in multiple sclerosis (Baker et al., 1964; Tichy et al., 1969). The cholesterol ester fraction shows the greatest decrease in linoleate content (Baker et al., 1965). Moreover, the decreased linoleate fraction is not peculiar to plasma lipids but also occurs in lipids of red cells and platelets (Gul et al., 1970). Previous work established that the fatty-acid composition of phosphatidylcholines (lecithins) from the brains of patients with multiple sclerosis differed from that of normal brain (Baker et al., 1963). Even in non-plaque areas saturated fatty acids increased relative to unsaturated fatty acids. Several other reports have shown changes in relative proportions of saturated and unsaturated fatty acids in brains of multiple sclerosis patients (Gerstel et al., 1961 ; Cumings et al., 1965; Arnetoli et al., 1969; Clausen and Hanson, 1970; Gerstel et al., 1970; Alling et al., 1971).

Previous studies compared linoleic acid composition of serum lipids in multiple sclerosis with levels in subjects with other neurological disorders and in healthy subjects (Baker et al., 1964; Belin et al., 1971). No comparison seems to have been made with diseases which did not have a neurological basis. We considered that it was essential to examine linoleic acid levels of serum lipids in non-neurological diseases before coming to a definite conclusion about the significance of altered linoleic acid levels in multiple sclerosis.

We therefore set out to compare the levels of serum linoleic acid in multiple sclerosis with levels found in acute hospital 
admissions suffering from diseases which did not have a neurological basis. For the purpose of comparison patients with neurological diseases other than multiple sclerosis and healthy subjects were also studied. Preliminary reports of this work have been published (Love et al., 1972, 1973). Some subjects selected from this study were included in a simultaneous dietary survey (Callaghan et al., 1973).

\section{Subjects and Methods}

The groups studied consisted of 47 patients with multiple sclerosis, 35 with a variety of acute non-neurological illnesses, 29 with neurological diseases other than multiple sclerosis, and 49 healthy control subjects.

\section{MULTIPLE SCLEROSIS PATIENTS}

The 47 patients with multiple sclerosis, whose ages ranged from 20 to 58 years (mean 39 years), were divided into three groups as follows: group 1 consisted of 14 patients (nine men, five women) who were seen during acute exacerbations of the disease. The incapacity of this group before the exacerbations was minimal and did not interfere with their normal daily activities. Their disability on admission to hospital was such that it was necessary to confine all patients to bed initially. Group 2 consisted of 21 cases (10 men, 11 women). This group showed progressive deterioration of the disease to the extent that it interfered with normal daily activities. The patients in this group were ambulant at the time of the investigation. Group 3 consisted of 12 cases (seven men, five women) permanently confined to bed or to a wheelchair.

Only patients whose clinical presentation was compatible with the criteria suggested by McAlpine et al. (1972) for definite cases of multiple sclerosis were included in the study.

\section{ACUTELY ILL PATIENTS}

Patients with acute non-neurological illness consisted of 15 men and 20 women. Their ages ranged from 20 to 55 years (mean 37 years). The patients were divided into those with infective and those with non-infective diseases. The group with infective diseases included 18 patients with acute respiratory infections, one with agranulocytosis with pharyngitis, and one with acute cholecystitis. The group with non-infective diseases was made up of three patients with myocardial infarction, three with severe anaemia, two with rheumatoid arthritis, two with peptic ulceration, two with carcinoma of lung, one with thyrotoxicosis, one with acute renal failure, and one with Hodgkin's disease.

\section{NEUROLOGICAL CONTROLS}

There were 12 men and 17 women with neurological diseases other than multiple sclerosis. Their ages ranged from 25 to 56 years (mean 38 years). The diseases studied in this group were as follows: acute disc lesions (six cases), epilepsy (five cases), spinal cord tumours (four cases), acute infective polyneuritis (two cases), cerebrovascular accidents (two cases), brain tumours (two cases), and ophthalmoplegic migrane, acute transverse myelitis, torsion dystonia, Parkinson's disease, motor neurone disease, spinal-cord arachnoiditis, dementia, and subacute combined degeneration of the cord (one case of each).

\section{HEALTHY CONTROL SUBJECTS}

The healthy subjects were selected from army personnel and hospital staff. The ages of the 33 men and 16 women ranged from 20 to 50 years (mean 35 years). All volunteered to take part in the trial.

\section{ANALYTICAL PROCEDURES}

Blood samples were taken from all subjects after an overnight fast. The serum was separated within two hours and stored at $-20^{\circ} \mathrm{C}$ until processed. Total lipids were extracted, hydrolysed, and the fatty-acid methyl esters prepared and analysed as described by Baker et al. (1964). The fatty-acid methyl esters were separated by gas-liquid chromatography using a $5 \mathrm{ft}(1.5$ m) metal column (1 mm bore) packed with $15 \%$ polyethylene glycol adipate on $80-120$ mesh diatomaceous celite at $190^{\circ} \mathrm{C}$ and a flame ionization detector in a Pye Series 104 chromatograph. The chromatograms were analysed by triangulation of the peaks and the individual fatty acids expressed as a percentage of total fatty acids. Serum cholesterol was determined by a modified Lieberman-Burchard reaction (Carr and Drekter, 1956).

By means of an appropriate code the person carrying out the biochemical analyses was not aware of the clinical diagnosis. Comparisons were made by Student's $t$ tests. These and other statistical calculations were made on an I.B.M. 1130 computer.

TABLE I-Fatty-acid Composition of Serum Lipids, expressed as Mean Percentage of Total Fatty Acids ( \pm S.E. of Mean), and Serum Cholesterol Values in Four Study Groups

\begin{tabular}{|c|c|c|c|c|c|c|}
\hline & & & $\begin{array}{l}\text { Healthy } \\
\text { Controls } \\
(\mathrm{n}=49)\end{array}$ & $\begin{array}{c}\text { Neurological } \\
\text { Controls } \\
(\mathbf{n}=29)\end{array}$ & $\begin{array}{c}\text { Multiple } \\
\text { Sclerosis } \\
\text { Patients } \\
(\mathrm{n}=47)\end{array}$ & $\begin{array}{l}\text { Acutely } \\
\text { III } \\
\text { Patients } \\
(\mathbf{n}=35)\end{array}$ \\
\hline $\begin{array}{l}\text { Myristic } \\
\text { Palmitic } \\
\text { Palmitoleic } \\
\text { Stearic ... } \\
\text { Oleic . } \\
\text { Linoleic } \\
\text { Others .. }\end{array}$ & $\begin{array}{l}\ldots \\
\cdots \\
\cdots \\
\cdots \\
\cdots\end{array}$ & $\begin{array}{l}. . \\
\because \\
\because \\
\because \\
\therefore \\
.\end{array}$ & $\begin{aligned} 1.5 & \pm 0.1 \\
23.5 & \pm 0.5 \\
5.3 \pm & 0.2 \\
9.5 \pm & 0.3 \\
29.3 \pm & 0.5 \\
27.0 \pm & 0.9 \\
3.9 & \pm .4\end{aligned}$ & $\begin{array}{r}1.2 \pm 0.1 \\
26.0 \pm 0.4 \\
6.1 \pm 0.3 \\
8.0 \pm 0.3 \\
33.7 \pm 0.6 \\
20.9 \pm 0.8 \\
4.0 \pm 0.2\end{array}$ & $\begin{array}{rl}1.5 & \pm 0.1 \\
25.2 & \pm 0.4 \\
6.0 \pm & 0.3 \\
8.6 \pm 0.2 & \pm \\
32.8 & \pm .5 \\
22.3 & 0.7 \\
3.5 & \pm 0.2\end{array}$ & $\begin{array}{r}1.4 \pm 0.1 \\
29.0 \pm 0.7 \\
6.7 \pm 0.3 \\
8.2 \pm 0.3 \\
35.5 \pm 0.8 \\
14.4 \pm 1.1 \\
4.2 \pm 0.3\end{array}$ \\
\hline \multicolumn{3}{|c|}{$\begin{array}{c}\text { Mean serum cholesterol } \\
\pm \text { S.E. of Mean } \\
(\mathrm{mg} / 100 \mathrm{ml})\end{array}$} & $231 \pm 11$ & $217 \pm 24$ & $275 \pm 13$ & $301 \pm 27$ \\
\hline
\end{tabular}

\section{Results}

The fatty-acid pattern in the various groups is shown in table 1, and the statistical relations of these patterns are summarized in table II. While we confirmed that linoleic acid levels were decreased in multiple sclerosis patients it was also apparent that a similar decrease occurred in neurological diseases other than multiple sclerosis and, even more strikingly, that the greatest decrease occurred in patients with acute illness of a nonneurological nature $(P<0.001$ in all groups). While serum linoleic acid levels decreased the non-essential fatty acids oleate and palmitate showed a significant increase in all the ill patients compared with healthy controls. A decrease in stearic acid levels seemed to accompany the increase in oleic acid in each group. Similarly palmitoleic acid levels also increased as linoleic acid levels decreased. Thus it seemed that as the essential unsaturated fatty acid-linoleic acid-decreased the unsaturated fatty acid stearic acid-a precursor of oleic acid-also decreased and palmitoleic acid and its precursor palmitic acid both increased.

The ratio of unsaturated fatty acids to saturated fatty acids remained remarkably constant despite the alterations in individual fatty acids (table III). In acute illness, however, the ratio showed a decrease.

When the multiple sclerosis patients were divided into groups according to the activity of the disease the lowest levels of linoleic acid were found in patients during acute exacerbations (group 1) and in those permanently confined to bed or wheelchair (group 3; table IV). Multiple sclerosis patients with progressive deterioration of the disease (group 2 ) had linoleic 
TABLE II-Significance of Changes in Fatty-acid Pattern and Serum Cholesterol Values

\begin{tabular}{|c|c|c|c|c|c|c|c|c|}
\hline & & & & $\begin{array}{c}\text { Multiple Sclerosis Patients } \\
v \text {. Healthy Controls }\end{array}$ & $\begin{array}{l}\text { Acutely Ill Patients } \\
v \text {. Healthy Controls }\end{array}$ & $\begin{array}{l}\text { Healthy Controls } \\
\text { v. Neurological Controls }\end{array}$ & $\begin{array}{l}\text { Neurological Controls } v \text {. } \\
\text { Multiple Sclerosis Patients }\end{array}$ & $\begin{array}{l}\text { Acutely Ill Patients } v \text {. } \\
\text { Multiple Sclerosis Patients }\end{array}$ \\
\hline $\begin{array}{l}\text { Myristic } \\
\text { Palmitic } \\
\text { Palmitoleic } \\
\text { Stearic } \\
\text { Oleic } 0 . \\
\text { Linoleic } \\
\text { Others } \\
\text { Cholesterol }\end{array}$ & $\begin{array}{l}\because \\
\because \\
\because \\
\because \\
\cdots \\
\cdots\end{array}$ & $\begin{array}{l}\because \\
\because \\
\because \\
\therefore \\
\cdots \\
\therefore\end{array}$ & $\begin{array}{l}\because \\
\because \\
\because \\
\because \\
\because \\
\because\end{array}$ & $\begin{aligned} \text { N.S. } & \\
0.01 & <\mathrm{P}<0.05 \\
0.01 & <\mathrm{P}<0.05 \\
0.01 & <\mathrm{P}<0.05 \\
\mathrm{P} & <0.001 \\
\mathrm{P} & <0.001 \\
\text { N.S. } & \\
0.01 & <\mathrm{P}<0.05\end{aligned}$ & $\begin{array}{l}\text { N.S. } \\
P<0.001 \\
P<0.001 \\
P<0.01 \\
P<0.001 \\
P<0.001 \\
N . S . \\
P<0.01\end{array}$ & $\begin{array}{c}\text { N.S. } \\
P<0.01 \\
P<0.05 \\
P<0.01 \\
P<0.001 \\
P<0.001 \\
\text { N.S. } \\
\text { N.S. }\end{array}$ & $\begin{array}{c}\text { P }<0.05 \\
\text { N.S. } \\
\text { N.S. } \\
\text { N.S. } \\
\text { N.S. } \\
\text { N.S. } \\
\text { N.S. } \\
0.01<\text { < }<0.05\end{array}$ & $\begin{array}{c}\text { N.S. } \\
P<0.001 \\
\text { N.S. } \\
\text { N.S. } \\
P<0.01 \\
P<0.001 \\
\text { N.S. } \\
\text { N.S. }\end{array}$ \\
\hline
\end{tabular}

TABLE III-Saturated and Unsaturated Fractions as Percentage of Total Fatty Acids in Serum Lipids

\begin{tabular}{|c|c|c|c|}
\hline & $\begin{array}{c}\text { \% Saturated } \\
\text { (Myristic } \\
\text { + Palmitic } \\
\text { + Stearic) }\end{array}$ & $\begin{array}{c}\text { \% Unsaturated } \\
\text { (Palmitoleic } \\
\text { + Oleic } \\
+ \text { Linoleic) }\end{array}$ & $\begin{array}{c}\text { Saturated } \\
+ \text { Unsaturated } \\
\text { (Sum of } 6 \\
\text { Acids only) }\end{array}$ \\
\hline $\begin{array}{l}\text { Healthy controls } \\
\text { Neurological controls .. } \\
\text { Multiple sclerosis }\end{array}$ & $\begin{array}{l}34 \cdot 5 \\
35 \cdot 2\end{array}$ & $\begin{array}{l}61 \cdot 6 \\
60 \cdot 7\end{array}$ & $\begin{array}{l}96 \cdot 1 \\
95 \cdot 9\end{array}$ \\
\hline $\begin{array}{cc}\text { patients } & \\
\text { Acutely ill patients } & \ldots\end{array}$ & $\begin{array}{l}35 \cdot 7 \\
38 \cdot 6\end{array}$ & $\begin{array}{l}61 \cdot 1 \\
56 \cdot 6\end{array}$ & $\begin{array}{l}96 \cdot 8 \\
95 \cdot 2\end{array}$ \\
\hline
\end{tabular}

TABle IV-Serum Total Fatty-acid Pattern in Multiple Sclerosis Patients, expressed as Mean Percentage of Total Fatty Acids ( \pm S.E. of Mean) and Serum Cholesterol Values

\begin{tabular}{|c|c|c|c|c|c|c|}
\hline & & & $\underset{(n=14)}{\text { Group } 1}$ & $\begin{array}{l}\text { Group } 2 \\
(\mathrm{n}=21)\end{array}$ & $\begin{array}{l}\text { Group } 3 \\
(\mathrm{n}=12)\end{array}$ & $\begin{array}{l}\text { Healthy } \\
\text { Controls } \\
(n=49)\end{array}$ \\
\hline $\begin{array}{l}\text { Myristic } \\
\text { Palmitic } \\
\text { Palmitoleic } \\
\text { Stearic .. } \\
\text { Oleic . . } \\
\text { Linoleic } \\
\text { Others .. }\end{array}$ & $\begin{array}{l}\ldots \\
\cdots \\
\cdots \\
\cdots \\
\cdots\end{array}$ & $\begin{array}{l}\cdots \\
\cdots \\
\cdots \\
\cdots \\
\cdots\end{array}$ & 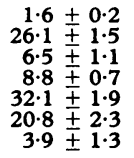 & $\begin{array}{r}1.4 \pm 0.2 \\
23.9 \pm 0.9 \\
5.7 \pm 0.8 \\
8.8 \pm \frac{1}{ \pm} \\
32.4 \pm \frac{1.5}{ \pm .4} \\
24.6 \pm 2.0 \\
3.0 \pm 0.5\end{array}$ & $\begin{array}{r}1.5 \pm 0.3 \\
26.4 \pm 1.3 \\
6.1 \pm 0.8 \\
8.1 \pm 1.0 \\
34.2 \pm 2.0 \\
20.0 \\
3.7 \pm 3.1 \\
1.7 \pm 1.1\end{array}$ & $\begin{array}{r}1.5 \pm 0.1 \\
23.5 \pm 0.5 \\
5.3 \pm 0.2 \\
9.5 \pm 0.3 \\
29.3 \pm 0.5 \\
27.0 \pm 0.9 \\
3.9 \pm 0.4\end{array}$ \\
\hline \multicolumn{3}{|c|}{$\begin{array}{c}\text { Mean serum Cholesterol } \\
\pm \text { S.E. of Mean } \\
(\mathrm{mg} / 100 \mathrm{ml})\end{array}$} & $217 \pm 52$ & $287 \pm 38$ & $325 \pm 32$ & $231 \pm 11$ \\
\hline
\end{tabular}

acid levels greater than those of 1 or 3 but lower than those of healthy controls.

Cholesterol levels were significantly higher than control levels in the patients with acute illnesses $(P<0.01)$ and multiple sclerosis $(P<0.05)$. Other workers have shown this reciprocal relation of linoleic acid levels and cholesterol levels (Coombes et al., 1962). The mean cholesterol level in plasma of the multiple sclerosis was lowest in group 1, was increased in group 2, and was greatest in group 3.

Thus linoleic acid levels were decreased not only in multiple sclerosis but also in other neurological disorders and even more so in acute non-neurological illnesses $(P<0.001$ in all cases when compared to healthy controls). Furthermore, patients with acute illness had linoleic acid levels significantly lower than those in multiple sclerosis $(P<0.001$; table II).

Within the acute-illness group there was no significant difference between linoleic acid levels of serum lipids in infective and non-infective illnesses.

\section{Discussion}

This study showed that the reduction in the levels of linoleic acid in the serum lipids was not restricted to multiple sclerosis. A highly significant reduction occurred in acute non-neurological diseases, in which the lowest levels were found. Unlike previous workers (Baker et al., 1964) we have shown a significant reduction in levels in neurological diseases other than multiple sclerosis. The lowest levels were present in acutely ill patients and in the most severely incapacitated multiple sclerosis patients, suggesting that the serum levels of linoleic acid are reduced in relation to the serverity of illness. It has previously been shown (Baker et al., 1964) that the levels fall with evidence of increased deterioration in patients with multiple sclerosis.

When one examines the fatty acid composition of serum lipids in the different groups in this study a definite pattern emerges. An inverse relation existed between linoleic acid levels on the one hand and palmitic, oleic, and palmitoleic acid levels on the other. The sum of the unsaturated acids (oleic, linoleic, and palmitoleic) was remarkably constant in each group except that with acute illness (see table III). Similarly, the sum of the saturated fatty acids was remarkably constant. These changes resembled those seen in essential fatty acid deficiency, where non-essential unsaturated fatty acids increase when there is a deficiency of essential fatty acids (Wiese, 1971).

Experiments in animals confirm that in linoleic acid deficiency palmitic, palmitoleic, and oleic acid synthesis is increased (Allman and Gibson, 1965; Allman et al., 1965). These workers have also shown an increase in cholesterol esters in tissues in linoleic acid deficiency, and, conversely, it has been shown that cholesterol and saturated fatty acid feeding increase linoleic acid requirements (Aaes-Jorgensen, 1961; Holman, 1960).

In this respect it is worth comment that we found that the lowest levels of linoleic acid were associated with the highest levels of palmitic acid, especially in patients with acute illness of a non-neurological origin. Furthermore, we have previously shown in a dietary survey that the lowest intake of linoleic acid occurred in this group (Callaghan et al., 1973). That the highest levels of cholesterol were also found in this group may be related to the observation that cholesterol accumulation is a feature of essential fatty acid deficiency (Coombes et al., 1962). It has also been shown that tissue levels of palmitoleic and oleic acids are increased when linoleic acid is deficient in the diet (Coombes et al., 1962).

Since our study has shown that alterations in the levels of linoleic acid occur in a wide variety of illnesses possibly a similar basis for the reduced levels may be present in all of the diseases studied. It has already been shown that linoleic acid absorption is normal in multiple sclerosis patients (Belin et al., 1971) and it is unlikely that any defect of absorption occurred in any of the diseases included in this study. In a simultaneous dietary survey a significant reduction in the intake of linoleic acid was shown only in patients with acute non-neurological illness (Callaghan et al., 1973). It is therefore possible that the changes that occurred in the fatty-acid pattern in illness were related to some disturbance of fatty-acid metabolism that occurred after the absorption of linoleic acid. It has previously been shown that low serum linoleic acid levels in cholesterol esters occur in patients with carcinoma of the liver (Zollner and Wolfram, 1961), among poor East Africans (Scott, 1963), among chronic alcoholics (Alling et al., 1967), and after dissection of the ileum (Collins et al., 1971). Linoleic acid content of serum free fatty acids, cholesterol esters, phospholipids, and triglycerides is reduced after myocardial infarction (Kirkeby, 1972 a; Kirkeby et al., 1972). Similar findings have been described after injection of growth hormone (Jurand and Oliver, 1970 a), after administration of thyroxine (Kirkeby, 1972 b), in hyperthyroidism (Kirkeby, $1972 \mathrm{c}$ ), and in hypothyroidism complicated by an infective illness (Kirkeby $1972 \mathrm{~d}$ ). The changes that are known to occur in linoleic acid levels in thyrotoxicosis may be relevant to this study since it has been shown by Harvey (1971) that free thyroxine levels are raised in 
seriously ill patients. He has suggested that the changes found may represent a normal response to acute medical stress. It is therefore possible that the changes in fatty-acid metabolism which occur during illness may have a similar basis. Kirkeby (1972 c) suggests that the alteration in the fatty-acid pattern may result from the actions of increased free thyroxine, such as increased synthesis of saturated and monounsaturated fatty acids, increased mobilization of depot lipids rich in oleic but poor in linoleic acid, and increased utilization of existing linoleic acid. Valtnere (1959) has presented some evidence that thyroid function is increased in multiple sclerosis. In contrast, other values which may be increased in stress-noradrenaline and adrenocorticotrophin-have been shown to increase linoleic acid content of serum lipids (Jurand and Oliver, $1970 \mathrm{~b}$, Kirkeby and Bjerkedal, 1972). A decreased level of linoleic acid in serum lipids may be a general phenomenon of acute illness and the similarity of the pattern to that of essential fatty-acid deficiency may reflect a greater need of essential fatty acids in illness.

The reduction in linoleic acid levels was not peculiar to multiple sclerosis but was associated with diseases of varied aetiology. It would therefore seem that reduced levels were not specific to any illness. There was no evidence that lower linoleic acid levels altered the progress of any of the diseases included in this study. Furthermore, we have recently shown (Callaghan et al., 1974) that lower serum linoleic acid levels persisted after clinical recovery in three cases of tetanus, three of viral meningitis, one of bacteraemia, one of cortical thrombophlebitis, and one of encephalitis. Though Millar et al. (1973) have shown in patients with multiple sclerosis that relapses were less frequent, and of shorter duration, after linoleic acid supplementation in the diet the overall rate of clinical derterioration was not altered. In view of the association of low linoleic acid levels with diseases other than multiple sclerosis we feel that the possible therapeutic benefit of dietary linoleic acid supplements in multiple sclerosis should be regarded with some reservation pending the results of further controlled studies.

We acknowledge the financial support of the Medical Research Council of Ireland and the Multiple Sclerosis Society of Ireland, and we thank Miss Horgan and Dr. O'Regan of the computer science division, University College, Cork, for their help in statistical analysis of data. It is a pleasure to record our thanks to Professor D. O'Sullivan for his encouragement throughout the project and permission to study patients under his care.

\section{References}

Aaes-Jorgenson, E. (1961). Physiological Reviews, 41, 1.

Alling, C. H., Vanier, M. T., and Svennerholm, L. (1971). Brain Research, $35,325$.

Alling, C. H., Dencker, S. J., Svennerholm, L., and Tichy, J. (1967). Lancet, 2, 312

Allman, D. W., and Gibson, D. M. (1965). Fournal of Lipid Research, 6, 51. Allman, D. W., Hubbard, D. D., and Gibson, D. M. (1965). Fournal of Lipid Research, 6, 63.

Arnetoli, G., Pazzagli, A., and Amaducci, L. (1969). fournal of Neurochemistry, 16, 461.

Baker, R. W. R., Thompson, R. H. S., and Zilkha, K. J. (1963). Lancet, 1, 26.

Baker, R. W. R., Thompson, R. H. S., and Zilkha, K. J. (1964). Fournal of Neurology, Neurosurgery and Psychiatry, 27, 408 .

Baker, R. W. R., Saunders, H., Thompson, R. H. S., and Zilkha, K. J. (1965). Fournal of Neurology, Neurosurgery and Psychiatry, 28, 212.

Belin, J., Petter, J., Smith, A. D., Thompson, R. H. S., and Zilkha, K. J. (1971). Fournal of Neurology, Neurosurgery and Psychiatry, 34, 25.

(1971). fournal of Neurology, Neurosurgery and Psychiatry, 34, 25.
Callaghan, N., Kearnery, B., and Love, W. C. (1973). Fournal of Neurology, Neurosurgery and Psychiatry, 36, 668.

Callaghan, N., Reynolds, M., and Love, W. C. (1974). In preparation

Carr, J. J., and Drekter, I. J. (1956). Clinical Chemistry, 2, 353.

Clausen, J., and Hanson, I. B. (1970). Acta Neurologica Scandinavica, 46, 1.

Collins, F. D., et al. (1971). Nutrition and Metabolism, 13, 150.

Coombes, M. A., Pratt, E. L., and Wiese, H. F. (1962). Paediatrics, 30, 136.

Cumings, J. N., Shortman, R. C., and Skrbict, T. (1965). Fournal of Clinical Pathology, 18, 641 .

Gerstel, B., Kahnke, M. J., Smith, J. K., Tavaststjerna, M. C., and Hayman, R. B. (1961). Brain, 84, 310.

Gerstel, B., Eng, L. F., Tavaststjerna, M. C., Smith, J. K., and Kruse, S. L. (1970). Fournal of Neurochemistry, 17, 677.

Gul, S., Smith, A. D., Thompson, R. H. S., Wright, H. P., and Zilkha, K. J. (1970). Fournal of Neurology, Neurosurgery and Psychiatry, 33, 506.

Harvey, R. F. (1971). Lancet, 1, 208.

Holman, R. T. (1960). Fournal of Nutrition, 70, 405.

Holman, R. T. (1960). Fournal of Nutrition, 70, 405.

Jurand, J. B., and Oliver, M. F. (1970 a). Atherosclerosis, 11, 146.

Jirkeby, K. (1972 a). Acta Medica Scandinavica, 192, 523.

Kirkeby, K. (1972 b). Acta Endocrinologica, 71, 73 .

Kirkeby, K. (1972 c). Acta Endocrinologica, 71, 62.

Kirkeby, K. (1972 d). Acta Endocrinologica, 71, 80.

Kirkeby, K., and Bjerkedal, I. (1972). Acta Medica Scandinavica, 192, 529.

Kirkeby, K., Ingvaldesen, P., and Bjerkedal, I. (1972). Acta Medica Scandinavica, 192, 513.

Love, W. C., Reynolds, M., Cashell, A., and Callaghan, N. (1972). Scandinavian fournal of Clinical and Laboratory Investigation, 29, Suppl. No. 126, 3.48.

Love, W. C., Reynolds, M., Cashell, A., and Callaghan, N. (1973). Biochemical Society Transactions, $1,141$.

McAlpine, D., Lumsden, C. E., and Acheson, E. D. (1972). Multiple Sclerosis: A Reappraisal, 2nd edn., p. 202. Edinburgh, Livingstone.

Sclerosis: A Reappraisal, 2nd edn., p. 202. Edinburgh, Li
Millar, J. H. D., et al. (1973). British Medical fournal, 1, 765.

Millar, J. H. D., et al. (1973). British Medical fournal, 1, 765. W. A. (1963). American fournal of Clinical Nutrition, 13, 82.

Thompson, R. H. S. (1966). Preceedings of the Royal Society of Medicine, $59,269$.

Tichy, J., Vymagal, J., and Michalec, C. (1969). Acta Neurologica Scandinavica, 45, 32.

Valtnere, A. L. (1959). Zhurnal Nevropatologii i Psikhiatri, 59, 523.

Wiese, H. F. (1971). In The Vitamins, ed. W. H. Sebrell and R. S. Harris, 2nd edn,. p. 3. New York, Academic Press.

Zollner, N., and Wolfram, G. (1961). Klinische Wochenschrift, 39, 817. 